\title{
Knowledge, Attitudes and Practices Associated with Waste Management in Jos South Metropolis, Plateau State
}

\author{
Audu Andrew Jatau \\ Department of Health and Physical Education, \\ Federal College of Education \\ Pankshin, Nigeria
}

\section{Doi:10.5901/mjss.2013.v4n5p119}

\begin{abstract}
This study determined the knowledge, attitudes and practices associated with waste management in Jos south metropolis. A cross-sectional survey design was employed for the study. A self developed knowledge, attitudes and practices associated with waste management questionnaire (KAPQ) was the instrument used for data collection. Data collected were analysed using frequency distribution, percentages, means, chi-square and t-test statistics. The findings of the study revealed that respondents with higher level of education (N.C.E/B.Ed) possessed corrected level of knowledge of the impact of improper waste management on health than those with lower level of education (TCII/SSCE). Age 31+ exhibit positive attitudes associated with waste management than age 15-30. Both TCII/SSCE and NCE/B.Ed holders exhibit positive practices associated with waste management. Level of education had statistical significant influence on knowledge of waste management. Age has no statistical significant influence on attitudes associated with waste management. Level of education had statical significant influence on practices associated with waste management. Based on these, the paper proffered suggestions on ways to curtail the problems of waste management.
\end{abstract}

Keywords: Knowledge, Attitudes, Practices, Waste management.

\section{Introduction}

Since the beginning, human kind has been generating waste, be it bones and other parts of animals they slaughter for their food or the wood they cut to make their fire. With the progress of civilization, Jatau (2007) noted that the waste generated became complex in nature and difficult to manage to the extent that not only did the air get more and more polluted, with the poor management of both biodegradable and non biodegradable solid waste. The increase in population and urbanization according to UNEPIETC (1996) were also largely responsible for the increase in solid waste.

The surveys of UNICEF (1999) and Hodges (2001) indicated an overall decline in access to sanitary means of excreta disposal between 1995 and 1999. In a latter year (2000), only 53 per cent of household enjoyed such facilities, roughly the same proportion as in Sub-Saharan African as a whole. Household in the urban areas (75 per cent) in 1999 were in much better situation than those in the rural areas (44 per cent). Access to adequate sanitary facilities deteriorated in all zones.

Amadi and Iwuala (2005) noted that recently, man has drastically altered his immediate environment through his day-to-day activities, in form of pollution, contamination or degradation. Polluted environment contains the multiplication and or development of different stages in the life cycle of the parasites and pests that pose threats to life. This therefore calls for proper waste management in Nigeria in general and Jos South metropolis in particular.

The term waste is described by Uchegbu (2002) as any garbage, sludge and gaseous and other discharged materials resulting from various community activities. He further added that waste consists of 
discarded materials resulting from domestic and community activities and from industrial, commercial and agricultural operation. Waste emanating from domestic and community activities requires effective management.

Waste management is defined by Uchegbu (2002) as a planned system of effectively controlling the production, storage, collection, transportation, processing and disposal or utilization of waste in a sanitary, aesthetically, acceptable and economic manner. The term waste management in this context is conceptualized as the care in manipulation, treatment, use or control of waste in an acceptable, aesthetically and economic manner.

Unfortunately, Nigeria seems to portray lukewarm attitudes towards waste management. No wonder Mobogunje (1999) asserted that the general deplorable and uninspiring characteristics of Nigeria cities continue to fester and appear as if there are no solutions to them. He further added that most of the wastes generated are not removed, and that in spite of the citizens cleaning their immediate environment, the inability of the local government to remove the numerous heaps of refuse all over the streets highlights the very poor level of waste management in Nigerian cities. Filth is thus a pervasive feature of most Nigerian cities and the poor have to survive and contend with this on daily basis due to inefficient urban waste management.

Over the past 20 years, Nigeria according to Uchegbu (2002) has witnessed rapid economic growth. This growth according to him, has given rise to the rising mountains of garbage, which now characterized most of our towns and cities. He further remarked that in the case of refuse, its collection and disposal have become the most glaring problem in Nigeria's urban areas which defied solution by both military and civilian administrators since Nigeria's independence. Discussing further, Uchegbu (2002) contended that the volume of waste generated by Nigeria's populace in cities, towns or villages are directly related to the population density. Lagos is a case in point where two-thirds of its gutters have become free range - part dumping grounds, part peering and part defecation. This can pose serious public health problems. Explaining further, Falomi (1995) identified two broad categories of Nigeria urban populace on the basis of their waste management attitude, which include:

1. the unconcerned elite who have an out-of-sight, out of mind attitude towards pile of waste, which they drive passed on streets enroute their offices, and

2. the ignorant poor who have an attitude of helpless resignation to living with the filth.

These negative attitudes of waste management undermine health. It is not surprising that UNICEF (1999) and Hodges (2001) studies found that the gaps in access to adequate sanitation remain very high in the rural areas. The study of Hodges (2001) indicated that about one third of rural households have no toilet facilities at all and as a result make use of the bush and rivers, while the study of UNICEF (1999) on environmental sanitation found that 40 per-cent of households did not have sanitary means of excreta disposal. The study further revealed that 48 per cent of rural dwellers dispose of solid waste in the bush, while 45 per cent used dumping sites. Only 9 per cent used garbage pits and 3 per cent burned their refuse. Many households according to the study (46 per cent) also did not allow their children to use latrines, even if these exist, mainly out of the fear that children may fall into pit ( 6 per cent) or mess up the latrine (52 per cent). These attitudinal problems underscore the need to accompany the construction of latrines with hygiene education.

Another major waste management problem in the urban areas as Hodges (2001) opined is lack of refuse collection. Waste management authorities collect refuse from households and public containers on a regular basis only in very few urban communities. As a result, most urban households resort to open dumping of refuse, engage private refuse collectors or burn or bury solid waste. He cited Lagos as an example where a survey in 1997 found that 21 per cent of households used dumping grounds, while 52 per cent employed the services of truck pushers to transport their solid waste to refuse skips. In most cities, the mounds of decomposing rubbish provide breeding grounds for rats, flies, and mosquitoes, contributing to 
unhealthy environment. The poor waste management attitudes and practices may be adduced to poor knowledge of the impact of improper waste management on health.

Sufficient knowledge of the impact of waste management on health may help people to protect themselves from diarrhea, typhoid fever, cholera, hepatitis, malaria and other infections. Adequate knowledge of the negative impact of poor refuse disposal may encourage people to adopt positive waste management practices and positive waste management practices may also promote personal hygiene and the health of the environs.

Despite various programmes by different tiers of government to address the issues of waste management, many Nigerians including the environs of Jos south metropolis seem to possess low level of knowledge, negative waste management attitudes and practices. Regrettably, the poor knowledge, attitudes and practices associated with waste management might have predisposed the environs of Jos south metropolis to the dangers of air born diseases such as whooping cough, asthma, measles, tuberculosis; water borne diseases such as typhoid fever, dysentery, cholera, hepatitis and insect/rodent borne diseases such as malaria, plague and Lassa fever. Diseases associated with poor waste management have caused numerous illnesses and the deaths of many Nigerians in general and Jos south metropolis in particular. This therefore necessitated the present study on knowledge, attitudes and practices associated with waste management in Jos south metropolis

\section{Research Questions}

In order to give direction to the study, the following research questions were posed:

1. What is the influence of level of education on the knowledge of the impact of improper waste management on the health of the environs of Jos south metropolis?

2. What is the influence of age on attitudes associated with waste management in Jos south metropolis?

3. What is the influence of level of education on practices associated with waste management in Jos south metropolis?

\section{Hypotheses}

In order to guide the study, the following null hypotheses were formulated and tested at .05 level of significance.

1. Level of education has no statistical significant influence on the knowledge of the impact of improper waste management on the health of the environs of Jos metropolis.

2. Age has no statistical significant influence on the attitudes associated with waste management in Jos south metropolis.

3. Level of education has no statistical significant influence on practices associated with waste management in Jos south metropolis.

\section{Methods}

In order to achieve the purpose of the study, a cross-sectional survey design was employed. Random sampling technique using balloting without replacement was employed to select 180 households in Jos south metropolis. A total of three hundred and eighty - nine (389) sample was drawn from the 180 randomly selected households in Jos south metropolis.

The instrument for data collection was forty - three item knowledge, attitudes and practices associated with waste management questionnaire (KAPQ). The questionnaire was categorized into four sections. Section A contained two socio-demographic variables of age and level of education. Section B elicited 
information on knowledge of the impact of improper waste management on health. This section required the respondents to indicate their level of knowledge by responding to True or False statement. Ashur's criterion of determining level of knowledge was employed. In this regard, a proportion less than 20 per cent was considered very low level of knowledge, 21 - 39 per cent low, 40 - 59 per cent average, 60 - 79 per cent high and above 80 per cent very high level of knowledge. Section $\mathrm{C}$ contained information on attitudes associated with waste management in Jos south metropolis, which provided four Likert scale of strongly agree (SA), agree (A), disagree (D), and strongly disagree (SD). Section D elicited information on practices associated with waste management, which provided response option of Very Often (VO), Often (O), Not Often (NO) and Never (N). Section C and D were scored using Likert scale of summated rating. The criterion mean of 2.5 was derived by adding all the weighted points and divide them by 4 . That is $4+3+2+1=$ $\frac{10}{4}=2.5$. Thus, a positive response was considered if the mean was equal to or greater than 2.5. Conversely, it was considered negative if the mean score was less than 2.5 .

The reliability of the questionnaire was obtained through a split half method which yielded a coefficient of .76. The face validity of the instrument was obtained through the judgment of five experts drawn from Health and Physical Education Department, psychology department and curriculum department of Federal College of Education, Pankshin.

The researcher and two trained research assistants visited 180 households in Jos metropolis and administered the questionnaire. The procedure for the completion of the questionnaire was explained to the respondents in the households selected for the study. Therefore, the completed copies of the questionnaire were collected on the spot. The data generated for the study were analysed using percentages and means to answer the research questions. While, Chi-square and t-test statistics were employed to test the hypotheses at .05 level of significance.

\section{Results}

The findings of the study are presented below according to research questions and hypotheses posed.

Table 1: Level of Knowledge of Impact of Improper Waste Management on Health According to Level of Education

\begin{tabular}{|c|c|c|c|c|c|c|c|c|c|}
\hline \multirow[t]{4}{*}{ S/NO } & \multirow[t]{4}{*}{ Items } & \multicolumn{8}{|c|}{ Level of Education } \\
\hline & & \multicolumn{4}{|c|}{$\begin{array}{c}\text { TCII/SSCE } \\
n=207\end{array}$} & \multicolumn{4}{|c|}{$\begin{array}{l}\text { NCE/B.Ed } \\
n=182\end{array}$} \\
\hline & & \multicolumn{2}{|c|}{ Correct } & \multicolumn{2}{|c|}{ Incorrect } & \multicolumn{2}{|c|}{ Correct } & \multicolumn{2}{|c|}{ Incorrect } \\
\hline & & f & $\%$ & $f$ & $\%$ & $f$ & $\%$ & $f$ & $\%$ \\
\hline 1 & $\begin{array}{l}\text { Dirty environment breeds flies which } \\
\text { precipitates the occurrence of dysentery and } \\
\text { diarrhea }\end{array}$ & 119 & 57.48 & 88 & 42.51 & 124 & 68.13 & 58 & 31.86 \\
\hline 2 & Flies cause the occurrence of intestinal worms & 109 & 52.65 & 98 & 47.34 & 120 & 65.93 & 62 & 34.06 \\
\hline 3 & $\begin{array}{l}\text { Improper management of waste pollute the } \\
\text { sources of water and cause hyphoid fever, } \\
\text { cholera and dysentery }\end{array}$ & 118 & 57.00 & 89 & 42.99 & 124 & 68.13 & 58 & 31.86 \\
\hline 4 & $\begin{array}{l}\text { Improper waste management precipitates the } \\
\text { occurrence of air pollution thereby causing } \\
\text { respiratory diseases }\end{array}$ & 104 & 50.24 & 103 & 49.75 & 118 & 64.83 & 64 & 35.16 \\
\hline 5 & $\begin{array}{l}\text { Improper managed waste attracts rodents } \\
\text { such as rats and mites, which transmit } \\
\text { diseases such as plaque and Lassa fever }\end{array}$ & 106 & 51.20 & 101 & 48.72 & 134 & 73.62 & 48 & 26.37 \\
\hline
\end{tabular}


6 Improper waste management attracts the multiplication of microorganisms, fungi, bacteria viruses which affects human health

7 Co-disposal of industrial waste with municipal waste exposes people to chemical and radioactive hazard

8 Improper managed waste when washed into sources of water causes hepatitis

9 Direct dumping of untreated waste into rivers, seas and lakes results in accumulation of toxic substances in food chain through the plant and animal that feed on it.
123

59.42

84

40.57

129

70.87

53

29.12

95

45.89

112

54.10

121

$66.48 \quad 61$

33.51

99

47.82108

52.17

98

53.84

84

46.15

$\begin{array}{lllllll}44.44 & 115 & 55.55 & 128 & 70.32 & 54 & 29.67\end{array}$

Grand \%

92

51.79

48.18

66.90

33.08

Table 1 reveals that NCE/B.Ed holders possessed correct level of knowledge than TCII/SSCE holders that: improper waste management attracts the multiplication of microorganisms, fungi, bacteria and viruses which affects human health (NCE/B.Ed holders 70.87\% > TCIISSCE holders 59.42\%) and direct dumping of untreated waste into rivers, seas and lakes results in accumulation of toxic substances in food chain through the plant and animal that feed on it (NCE/B.Ed holders 70.32\% > TCII/SSCE holders 44.44\%). Similarly, the table indicates that NCE/B.Ed holders possessed correct level of knowledge than TCII/SSCE holders that: improper managed waste attracts rodents such as rats and mites which transmit diseases such as plaque and Lassa fever (NCE/B.Ed holders 73.62\% > TCII/SSCE holders 51.20\%), improper management of waste pollutes the sources of water and cause typhoid fever, cholera and dysentery (NCE/B.Ed holders 68.13\% > TCII/SSCE holders 57.00\%), dirty environment breeds flies which precipitates the occurrence of dysentery and diarrhea (NCE/B.Ed holders $66.48 \%>$ TCII/SSCE holders 45.89\%). The overall results show that NCE/B.Ed holders possessed higher and correct level of knowledge than TCII/SSCE holders (NCE/B.Ed holders $66.90>$ TCII/SSCE holders 51.79\%).

Table 2: Attitudes Associated with Waste Management According to Age

\begin{tabular}{llcc}
\hline S/NO & Items & \multicolumn{2}{c}{ Age } \\
& & $\begin{array}{c}\text { Age } 15-30 \\
\mathrm{n}=203\end{array}$ & $\begin{array}{c}\text { Age 31+ } \\
\mathrm{n}=186\end{array}$ \\
& & mean $(\bar{x})$ & mean $(\bar{x})$ \\
\hline 10 & Dumping refuse in a specific open place & 3.01 & 2.98 \\
11 & Dumping refuse in any open place & 1.97 & 1.92 \\
12 & Dumping refuse on the main road & 2.23 & 3.09 \\
13 & Dumping refuse at the backyard & 2.38 & 2.25 \\
14 & Dumping refuse in depots & 2.64 & 2.5 \\
15 & Dumping my household refuse in cartons & 2.01 & 1.85 \\
16 & Dumping refuse in open dumps & 2.44 & 3.0 \\
17 & Dumping household refuse in metal containers & 2.09 & 2.36 \\
18 & Burying household refuse under the ground & 2.91 & 2.86 \\
19 & Burning household refuse with fire & 2.98 & 2.85 \\
20 & Dumping household wastes in nearby rivers & 2.09 & 2.36 \\
& Grand Mean & 2.43 & 2.54 \\
\hline
\end{tabular}


Table 2 shows that age 15-30 exhibit positive attitudes of waste management than age 31+ by: dumping refuse in specific open places (age 15-30 $=3.0 \bar{x}=>$ age $31+\bar{x}=2.98$ ), dumping refuse in refuse depots (age $15-30 \bar{x}=2.91>$ age $31+\bar{x}=2.86$ ) and burning household refuse with fire (age 15-30 $\bar{x}=$ $2.98>$ age $31+\bar{x}=2.85$ ). On the other hand, the table reveals that age $31+$ exhibit positive attitudes of waste management than age 15-30 by: avoiding dumping refuse on the main roads (age $31+\bar{x}=3.09>$ age 15 $30 \bar{x}=2.23$ ) and dumping refuse on open dumps (age $31+\bar{x}=3.0>$ age $15-30 \bar{x}=2.44$ ). The overall grand means indicate that age $31+$ exhibit positive attitudes of waste management slightly than age $15-30$ (age $31+\bar{x}=2.54>$ age $15-30 \bar{x}=2.43$ ).

Table 3: Practices Associated with Waste Management According to Level of Education

\begin{tabular}{|c|c|c|c|}
\hline S/NO & Items & $\begin{array}{c}\text { Age } 15-30 \\
\mathrm{n}=203 \\
\overline{-} \\
\text { mean }\left({ }^{x}\right)\end{array}$ & $\begin{array}{c}\text { Age } 31+ \\
\mathrm{n}=186 \\
-\bar{x}) \\
\text { mean }\left({ }^{2}\right)\end{array}$ \\
\hline 21 & Dumping refuse in open drains/gutters & 3.12 & 3.13 \\
\hline 22 & Dumping household waste on refuse heap on the street & 2.69 & 2.94 \\
\hline 23 & Dumping household waste in market places & 2.89 & 3.30 \\
\hline 24 & $\begin{array}{l}\text { Dumping household waste on the heaps of mountains of } \\
\text { garbage on high ways }\end{array}$ & 2.33 & 2.96 \\
\hline 25 & Defecating on streets & 2.50 & 2.64 \\
\hline 26 & Defecating in open place (free range system) & 2.64 & 2.73 \\
\hline 27 & Dumping babies excreta on streets & 3.24 & 2.64 \\
\hline 28 & Dumping waste in rivers & 3.27 & 2.66 \\
\hline 29 & Dumping animal excreta on heap of refuse & 2.77 & 2.80 \\
\hline 30 & Dumping animals faeces in open farms to serve as manure & 2.96 & 3.26 \\
\hline \multirow[t]{2}{*}{31} & Dumping agricultural waste on the farms & 2.73 & 3.13 \\
\hline & Grand Mean & 2.83 & 2.92 \\
\hline
\end{tabular}

Table 3 indicates that the practices of waste management according to level of education were: avoiding dumping refuse in open drains TCII/SSCE $\bar{x}=3.12<$ NCE/B.Ed $\bar{x}=3.13$ ), avoiding dumping household waste on refuse heap on the street (NCE/B.Ed $\bar{x}=2.94>$ TCII/SSCE $\bar{x}=2.69$ ), avoiding dumping household waste in market places (NCE/B.Ed $\bar{x}=3.30>\operatorname{TCII} / \mathrm{SSCE} \bar{x}=2.89$ ), dumping animals faeces in open farms to serve as manure NCE/B.Ed $\bar{x}=3.26>$ TCII/SSCE $\bar{x}=2.96$ ), dumping agricultural waste on farms (NCE/B/Ed $\bar{x}=3.13>$ TCII/SSCE $\bar{x}=2.73$ ), dumping babies excreta on streets (TCII/SSCE $\bar{x}=3.24>$ NCE/B.Ed $\bar{x}=2.66$ ). The overall grand means reveal that NCE/B.Ed holders exhibit positive practices of waste management slightly higher than TCII/SSCE holders (NCE/B.Ed $\bar{x}=2.92>$ $\operatorname{TCIISSCE} \bar{x}=2.83)$.

Table 4: Summary of Chi-square Verifying the Influence of Level of Education on Knowledge of Waste Management

\begin{tabular}{lccccl}
\hline Variable & Cal. $x^{2}$ & Tab. $x^{2}$ & Level of significance & Df & Decision \\
Level of Education & 15.79 & 3.84 & .05 & 1 & Rejected \\
\hline
\end{tabular}


Table 4 shows that the calculated chi-square value is more than the table chi-square (cal. $x^{2}=15.79>$ tab. $\left.x^{2}=3.84, p<.05\right)$. Since the calculated chi-square value is more than the table chi-square value, the null hypothesis of no significant difference was rejected. This implies that level of education had statistical significant influence on waste management.

Table 5: Summary of t-test Difference in the Influence of Age on Attitudes Associated with Waste Management

\begin{tabular}{lcccccccc}
\hline Group & No. & $\bar{x}$ & SD & Df & Level of Education & t-cal & t-tab & Decision \\
Age 15-30 & 203 & 2.43 & .43 & & & & & \\
Age 31+ & 186 & 2.54 & .41 & 378 & .05 & 0.77 & 1.96 & Accepted \\
\hline
\end{tabular}

Results in table 5 show that the calculated t-test value of 0.77 at 387 degrees of freedom is less than the t-table value of 1.96 at .05 level of significance (t-cal $=0.77<\mathrm{t}$-tab $=1.96 \mathrm{p}<.05$ ). The null hypothesis of no significant difference in the influence of age on attitudes associated with waste management is accepted. This implies that there was no statistical significant difference in the influence of age on attitudes associated with waste management.

Table 6: Summary of t-test Difference in the Influence of Level of Education on Practices Associated with Waste Management

\begin{tabular}{lcccccccc}
\hline Group & No. & $\bar{x}$ & SD & Df & Level of Education & t-cal & t-tab & Decision \\
NCE/B.Ed & 182 & 2.92 & .16 & & & & & \\
TCII/SSCE & 207 & 2.83 & .37 & 387 & .05 & 3.78 & 1.96 & Rejected \\
\hline
\end{tabular}

Results in table 6 reveal that the calculated t-value of 3.78 at 387 degrees of freedom is greater than the t-table value of 1.96 at .05 level of significance ( $t$-cal $=3.78>t$-tab $=1.96, p>.05$ ). Therefore, the null hypotheses of no significant difference in the influence of level of education on practices associated with waste management is rejected. This implies that there was statistically significant difference on the influence of level of education on practices associated with waste management.

\section{Discussion}

The overall results in table 1 revealed that NCE/B.Ed holders possessed correct level of knowledge of the impact of improper waste management than TCII/SSCE holders. This finding is not surprising because it is expected that level of education should have influence on knowledge of the impact of improper waste management. This finding corroborates that of Samuel (2006) who found that primary six school pupils possessed higher knowledge of refuse and sewage disposal than the pupils in the lower classes. Most of the respondents in the higher primary school level according to the study of Samuel demonstrated higher level of knowledge that pests and vectors can breed diseases when there is stagnant water in the environment; drainage blockage, inappropriate refuse disposal and lack of personal hygiene than the pupils at the lower class levels. Further more, the study revealed that most of the pupils in primary six knew the pests and vectors which affect health than the pupils in the lower classes.

Results in table 2 showed that age 15 - 30 exhibit positive attitudes of waste management of dumping refuse in specific open places, dumping refuse in refuse depot, burying household refuse under the ground and burning household refuse with fire. This is not surprising because the Government of Nigeria over the 
years has emphasized the need to cultivate positive attitudes towards waste management to all age groups. However, despite the emphasis on proper waste management, Nigerians seem to exhibit negative waste management attitudes. This finding negates that of Hodges (2001) who found that one - third of rural households had no toilets facilities at all and as a result made use of the bush and rivers. The finding further disagrees with that of UNICEF (1999) who found that 40 per cent of household resorted to the attitudes of open field defecation and that 56 per cent of rural household did not have sanitary means of excreta disposal. Similarly, the study of Hodges (2001) found that 48 per cent of rural dwellers dispose of solid waste in the bush, while 45 per cent used dumping sites. Only 9 per cent used garbage pits to dump their refuse. Many households (46 per cent) did not allow their children to use latrines, even if these exist, mainly out of fear that children may fall into the pit (60 per cent) or mess the latrine (52 per cent). These attitudinal problems associated with waste management underscore the need to accompany the construction of latrines with hygiene education.

Overall results in table 3 revealed that NCE/B.Ed holders exhibit positive practices associated with waste management than TCII/SSCE holders. This finding is not surprising because the level of one's education more often than not, influences practices associated with waste management. The finding corresponds with the view of Hodges (2001) who asserted that as a result of waste management Authority's failures to collect refuse from household on regular basis, most urban households resorted to the practices of open dumping of refuse and engaging private refuse collectors or burn or bury solid waste. His study further found that 21 per cent of household develop the practices of dumping waste on the ground, while 52 per cent employed the services of truck pushers to transport their solid waste to the refuse skips. In most cities where practices associated with waste management are poor, the mound of decomposing rubbish provides breeding grounds for rats, flies and mosquitoes contributing to the unhealthy living environment.

This finding negates that of Hodges (2001) who found that the proportion of the urban population with no toilet of any kind rose from $8-12$ per cent and 25 per cent of the urban population in Nigeria did not have any sanitary means of excreta disposal. These figures are especially alarming as they imply that large number of people develop the practice of urinating and defecating in open places, which poses serious health implications in densely populated urban settlements. The finding also disagrees with that of Stoveland and Bassey (2000) who found that refuse collection was almost non-existent in small towns, with only 41 per cent of household enjoying such a service, and about two thirds of households resorted to the practices of open dumping of solid waste, with the risks such method entail for health and the environment. This situation was made worse by the fact that only 14 per cent of small towns in Nigeria have organized public waste disposal sites. Over 63 per cent of households perceived environmental and health problem with the current refuse disposal methods they were practicing.

The results in table 4 indicated that the calculated chi-square value is more than the table chi-square value. This implies that level of education has statistical significant influence on the knowledge of the impact of improper waste management on health. This finding corresponds with the finding of Samuel (2006) who found that level of education had statistical significant influence on the knowledge of environmental sanitation.

Table 5 revealed that the calculated t-test value is less than the table t-value. This implies that age has no statistical significant influence on attitudes associated with waste management. This finding is surprising because one expected that age 31+ would exhibit positive attitudes associated with waste management than age $15-30$.

The results in table 6 revealed that the t-test value is more than the table t-value. This implies that level of education has statistical significant influence on practices associated with waste management. The finding is not surprising and therefore expected because those with higher level of education were expected to exhibit more positive waste management practices than those with lower level of education. 


\section{Conclusion and Recommendations}

Based on the findings of the study, it was concluded that most respondents with higher level of education (NCE/B.Ed) possessed correct level of knowledge of the impact of improper waste management on health than those with lower level of education (TCII/SSCE). Age 31+ exhibited positive attitudes associated with waste management than age $15-30$. Both TCII/SSCE and NCE/B.Ed holders exhibit positive practices associated with waste management. Level of education had statistical significant influence on knowledge associated with waste management. Age has no statistical significant influence on attitudes associated with waste management. Level of education had statistical significant influence on practices associated with waste management.

Based on the findings of the study, the following recommendations were proffered:

1. Federal, States and Local Governments should promulgate and enforced policies on waste management.

2. Knowledge on waste management should be promoted. Those with lower level of education should be the focus group. This can be achieved through organizing workshops, seminars and conferences on waste management by environmental sanitation authorities and public health educators.

3. The Federal and Non-governmental organizations should sponsor people to undertake community based projects on knowledge, attitudes and practices associated with waste management. This will help to create awareness as well as alter the negative attitudes and practices related to waste management.

\section{References}

Amadi, A.N \& Iwuala, M.O.E (2005). Environmental sanitation and the prevalence of parasitic infections in Abia State, Nigeria. Journal of Environmental Health (2), 69 - 74.

Ashur, S.S. (1977). An evaluation plan for the development and upgrading of nutrition curriculum at upper elementary and preparatory levels in Jordan. IVES/UNESCO International Conference in Nutrition Education, NE/Oxford 207(2): 6764.

Falomi, A.A (1995). City waste as a public nuisance. A paper presented at Annual Conference of the Nigerian Environmental Society, Lagos.

Hodges, A.O. (2001). Children's and Women's right in Nigeria: A wake-up call. Abuja: National Planning Commission, Nigeria/UNICEF.

Jatau, A.A. Effective waste management. A tool for achieving sustainable development in Nigeria. Journal of Environmental Studies (3), 2,77-82.

Mobogunje, A.L. (1999). Cities for all the challenges for Nigeria, Abuja Federal Ministry of Works and Housing.

Samuel, E.S. (2006). Environmental sanitation knowledge among primary School pupils in Idemili North Local Government Area of Anambra State. Journal of Environmental Health (3) 1, 5- 12.

Stoveland, S., \& Bassey, B.U. (2000). Status of water supply and sanitation in 37 small towns in Nigeria. A paper presented at the Donor conference, $2^{\text {nd }}-4^{\text {th }}$ Feb.

Uchegbu, S.N. (2002). Environmental management and protection, $2^{\text {nd }}$ ed. Enugu: Spot life publishers.

UNEP-IETC (1996). International source book on environmental sound technologies for municipal solid waste management. Technical publication series No 6 Osaka/Shagai UNEF International Environmental Technology Centre. $421-427$.

UNICEF (1999). Water and environmental sanitation programme study on knowledge, attitude and practices (zone $A, B, C, D)$, UNICEF, Lagos. 
